\title{
Review
}

\section{Political theory after Deleuze}

\author{
Nathan Widder \\ Continuum, London \& New York, 2012, xi+197pp., ISBN: 978-1-4411-5088-2 \\ Contemporary Political Theory (2015) 14, e27-e30. doi:10.1057/cpt.2014.41; \\ published online 9 December 2014
}

Nathan Widder's introductory book on Deleuze and political theory is part of a series geared towards student readers. With this audience in mind, the book succeeds in offering an accessible rendition of some of Deleuze's densest philosophical concepts, in familiarizing its readers with current debates in political theory and in situating Deleuze's work within them. Yet Widder's book has much to offer established scholars as well as students. Its interpretative insights regarding Deleuze's deployment of the work of Bergson, Nietzsche, Lacan and Sartre among others are likely to be especially edifying for advanced scholars. Further, two of its most pronounced interpretative threads stand out as promising to enliven conversations among all audiences. The first is Widder's contention that, from the early to late days of his thought, Deleuze's ontology is one of 'sense' (p. 22). This contention illustrates the special place that aesthetics has in Deleuze's work and its implications for his politics, while also unifying Deleuze's work across his lifespan. The second is Widder's argument that Deleuze's work offers a crucial corrective to the foundational role that much of contemporary political theory continues to reserve for subjectivity and its offshoots. Widder contends that, for Deleuze, subjectivity is a crucial medium for political change, yet is not foundational to political life. Rather, subjectivity is a surface effect of a 'micropolitics' in which aesthetics is key (p. x).

The first chapter of the book stands out for its merits as an introduction to contemporary debates in political theory. It opens with a narrative overview of political theory's recent 'ontological turn', a return to in-depth considerations of the most fundamental aspects of human existence as they pertain to politics and ethics (p. 1). Widder situates this turn against the backdrop of a liberal tradition that often reduces the political subject to a purely rational agent devoid of the markers of particular, lived experience and of social identity, while also reducing politics to questions of distribution, fair procedures and institutional structures (pp. 2-7). The book then moves on to address three divisive tracks along which political theory's ontological turn might run: the paths of strong or weak ontology, of lack or abundance and of immanence or transcendence. At each turn, Widder reflects on

(C) 2015 Macmillan Publishers Ltd. 1470-8914 Contemporary Political Theory Vol. 14, 3, e27-e30 www.palgrave-journals.com/cpt/ 
Deleuze's alignment along the divides. This methodological scaffolding gives students a structure on which to begin to build a sense of current debates within the field, and makes some quite sophisticated distinctions palatable.

In developing its position on sense as well as subjectivity in Deleuze's philosophy, Widder's book also offers readings of Deleuze's encounters with Bergson, Lacan and Sartre that are particularly discerning. Chapter 2 makes some intriguing comments on a lingering commitment to a transcendent ego in Bergson's philosophy, and links these commitments to a more ambiguous relationship between Deleuze and Bergson than is often acknowledged (p. 47). In Chapter 4, Widder works to disambiguate Deleuze and Guattari's criticisms of psychoanalysis in Anti-Oedipus from their affinity for certain aspects of Lacan's thought. Specifically, Widder finds Deleuze and Guattari arguing for the 'Real' in Lacan's work as a realm in which desire bears no relation to lack (p. 104). In Chapter 5, Widder also deftly traces the influence of Sartre's early work, The Transcendence of the Ego, on Deleuze's view of the subject (pp. 136-140). Deleuze's debts to Sartre, as well as the ambiguities of his relationship to both Lacan and Bergson, are aspects of his work that haven't yet received sufficient attention. Widder wakes readers to their import.

The book's linked contentions regarding sense and subjectivity resound throughout the whole. Widder's account of Deleuze's ontology of sense begins with a reading of one of Deleuze's very first publications, a review of Jean Hyppolite's Logic and Existence published in 1954. 'An ontology of sense', writes Widder, '... holds ... that appearances ... present only the illusion of essences lying underneath them, when in fact there is nothing [he later adds: "-or, rather, there is only difference-"] underneath' (pp. 23, 58). He enriches this account in Chapter 3 through attention to Deleuze's book on Nietzsche, which begins with attributing 'the introduction of the concepts of sense and value into philosophy' to him (p. 64; quoting Deleuze, 1983, p. 1). According to Widder, Deleuze found in Nietzsche a thinker for whom values, in Deleuze's words, were 'perspectives of appraisal' (quoting NP p. 1) that emerge from 'the way the world constitutes us and conditions the emergence of our subjectivity' (p. 64).

In the book's last and most explicitly political chapter, one can note a third development in Widder's articulation of Deleuze's ontology of sense. Here, Widder argues that this ontology entails that aesthetics do not stand outside politics, but infiltrate it. An encounter with that which can only be sensed is something that can shake one from one's settled identity, feelings and values, and open one to change (p. 128). A repeated, helpful example of such an encounter in the book is that of Foucault's perceptions of the prison system, which led to the establishment of the Prison Information Group (Groupe d'Information sur les Prisons) (for example, pp. 52-53). For Deleuze, Foucault was able to spearhead this political alliance because he saw something that was utterly intolerable; something that 'was no secret' - that in fact '[e]veryone knew about' - and yet no one saw (p. 53; quoting Deleuze, 2006, pp. 274-275). Social and political change can follow from achieving the kind of 
change in one's own sensibility that allows one to see the intolerable, that which is more than merely unjust precisely because it is known and yet not seen.

Yet for all the merits of Widder's reading in drawing attention to the role of aesthetics in both Deleuze's politics and ontology, it is nonetheless somewhat disconcerting to find a very early version of Deleuze's position on aesthetics made so key to his whole corpus. One worry is that this manoeuvre may leave readers with an exaggerated sense of Deleuze's debt to the phenomenological tradition. A connected concern is that this reading misses a shift away from the language of 'sense' towards 'sensation' in Deleuze's later work that emerges from a heightened sensitivity to the associations with normative, unified sensory experiences the former term carries in phenomenology. This move is exemplified, for instance, in Deleuze's book on Francis Bacon (Deleuze, 1981). Although Widder's easy transitions between accounts of sense in various works by Deleuze - as well as by Deleuze and Guattari illuminate the ongoing importance of aesthetics in this corpus, they also risk suggesting a surprising absence of transformative thinking about sense and sensation in his work. For these reasons, I'm left with a lingering feeling that this aspect of the book is both one of its greatest assets and also one of most contentious points.

The other continuous thread in the book is Widder's contention that subjectivity is crucial to political change for Deleuze, although it is not the foundation of political life. Chapter 3 takes up Deleuze's book on Nietzsche in its first concerted effort to develop this point. Widder identifies the Nietzschean task of overcoming, which requires a transvaluation of values and is linked to the eternal return, as one in which 'the ethical and the political meet' (p. 88). Overcoming ushers in a transformation of one's mode of life - an ethical change, yet does so through establishing constitutive ties to new forces that wash away the very subject that ushers it in - a micropolitical event (p. 85). Chapter 4 delves further into the study of the constitutive relations that precede subjectivity together with the micropolitics that precedes politics, whereas Chapter 5 is the book's explicit chapter on the concept of micropolitics. Against those who argue that the aesthetic has 'little to do with politics', Widder reads Deleuze's work as revealing that 'an aesthetic dimension of politics is inescapable' (pp. 20, 125). The chapter also develops the idea that '[a]cting, feeling and thinking' abilities generally tethered to a subject - do not emerge from out of subjectivity but rather guide subjectivity into the world (p. 136). The conclusion of the book introduces a difference between 'a life' and the life of a subject to bring home its thesis on the relation subjectivity bears to politics. Political change begins with $a$ life, born of connections and not of 'separateness and atomization', and passes through the subject, which holds the reins of a life's present tense, to usher in change at the level of subjectivity itself, of social systems and of institutions (p. 152).

Widder's book is to be praised for its sensitivity to the subject's crucial place in bringing about political change - something less attentive readers miss in Deleuze while also illuminating the extent to which politics neither begins nor ends with the subject. Still, if I could ask for more at the end of this outstanding book, it would be 
further consideration of why it is that political theory's strong investments in the subject as the centre point of political life have been so adamantly maintained, especially in the wake of the critiques of subjectivity for which philosophers such as Deleuze are known. Taking up possible objections to the role maintained for the subject in Deleuze's work would help Widder convince his audience that Deleuze's attention to the constitutive relationships through which subjectivity arises offers political theory a needed corrective - a corrective that enriches understandings of the political and ethical importance of subjective life, rather than stripping the subject bare.

\section{References}

Deleuze, G. (1981) In: Daniel W. Smith (trans.) The Logic of Sensation. London; New York: Continuum. Deleuze, G. (1983) In: H. Tomlinson (trans.) Nietzsche and Philosophy. London: Athlone press.

Deleuze, G. (2006) In: D. Lapoujade (ed.), A. Hodges and M. Taormina (trans.) Two Regimes of Madness: Text \& Interviews, 1975-1995. New York: Semiotext(e).

Katharine Wolfe

Allegheny College, Meadville, PA 16335, USA

e30 (c) 2015 Macmillan Publishers Ltd. 1470-8914 Contemporary Political Theory Vol. 14, 3, e27-e30 